\title{
CRLF2 Gene Mutation
}

National Cancer Institute

\section{Source}

National Cancer Institute. CRLF2 Gene Mutation. NCI Thesaurus. Code C150491.

A change in the nucleotide sequence of the CRLF2 gene. 